\title{
Sight Singing sebagai Strategi Pembelajaran Instrumen Piano di Prodi Pendidikan Musik ISI Yogyakarta
}

\author{
Suryati $^{1}$ dan Tri Wahyu Widodo \\ Prodi Pendidikan Musik, Fakultas Seni Pertunjukan, Institut Seni Indonesia Yogyakarta
}

\begin{abstract}
Sight Singing as the Learning Strategy of Piano Instrument at Music Education Study Program ISI Yogyakarta . Sight Singing can read the notation and immediately sing the tune following the melody on the sheet music. Sight Singing is the activity of singing with solmisasi or movable "do." This study aims to improve the ability to read beam notation in learning mandatory piano instruments using the Sight Singing approach. The Mandatory Piano Instrument course is one of the practical lessons taken by all Music Education Study Program students, ISI Yogyakarta. Not all new Music Education Study Program students can read the beam notation, so this Piano Compulsory Instrument course is always feared by students who have not read the fluent note. Sight-singing is a strategy to enhance the learning of Piano Mandatory Instruments. This research is focused on the application of Sight-singing in learning Mandatory Piano Instruments in the Music Education Study Program. This research uses Classroom Action Research, which can be categorized as qualitative-experimental research by applying the Sight-singing method. Classroom Action Research has a significant role in efforts to improve the quality of the learning process. This study's results are the Mandatory Piano Instrument learning process with the application of the Sight-singing method more effectively to improve the ability to learn to read notation while playing the Piano Instrument, and students can be more expressing, impressed singing by accompanying themselves.
\end{abstract}

Keywords: sight singing; learning; piano instrument

\begin{abstract}
ABSTRAK
Sight Singing adalah kemampuan membaca notasi dan langsung menyanyikan nada sesuai dengan melodi pada partitur musik. Sight Singing adalah aktivitas menyanyi dengan solmisasi atau movabel "do". Penelitian ini bertujuan untuk meningkatkan kemampuan membaca notasi balok dalam pembelajaran Instrumen Wajib Piano dengan menggunakan pendekatan Sight Singing. Mata kuliah Instrumen Wajib Piano adalah salah satu mata kuliah praktik yang harus ditempuh seluruh mahasiswa Prodi Pendidikan Musik, ISI Yogyakarta. Mahasiswa baru di Prodi Pendidikan Musik tidak semua bisa membaca notasi balok, sehingga mata kuliah Instrumen Wajib Piano ini selalu ditakuti oleh mahasiswa yang belum lancar membaca notasi balok. Sight singing sebagai strategi untuk meningkatkan pembelajaran Instrumen Wajib Piano. Penelitian ini terfokus pada penerapaan Sight singing dalam pembelajaran Instrumen Wajib Piano di Prodi Pendidikan Musik. Penelitian ini menggunakan Penelitian Tindakan Kelas yang dapat dikategorikan sebagai penelitian kualitatif-eksperimen dengan melakukan penerapan metode Sight singing. Penelitian Tindakan Kelas (PTK) memiliki peran yang sangat penting dalam upaya meningkatkan kualitas proses pembelajaran. Hasil dari penelitian ini menunjukkan proses pembelajaran Instrumen Wajib Piano dengan penerapan metode Sight singing lebih efektif untuk meningkatkan kemampuan belajar membaca notasi sambil memainkan Instrumen Piano, dan mahasiswa bisa lebih berekspresi, terkesan menyanyi dengan mengiringi sendiri.
\end{abstract}

Kata kunci: sight singing; pembelajaran; instrumen piano

Alamat korespondensi: Prodi Pendidikan Musik, Fakultas Seni Pertunjukan, Institut Seni Indonesia Yogyakarta. E-mail: atik.jurasik@yahoo.com; HP.: 085872874142. 


\section{Pendahuluan}

Sight singing merupakan salah satu aspek dalam pembelajaran solfegio. Sight singing adalah kemampuan membaca notasi musik dan langsung menyanyikan nada sesuai dengan melodi pada partitur musik, yang biasanya disebut prima vista (pandangan pertama). Pembelajaran solfegio menerapkan 3 aspek yaitu ear training (mendengar), sight singing (menyanyi), dan sight reading (membaca) yang saling berkaitan dalam pembelajan musik (Winata, 2015). Hal ini juga diungkapkan oleh Stanly dalam Sumaryanto yang mengatakan bahwa salah satu kegiatan dalam Solfegio adalah Sight singing, yaitu aktivitas menyanyi nada-nada dengan solmisasi atau movabel "do" (Sumaryanto, 2005). Akan tetapi dalam perkembangannya Solfegio, selain kemampuan menyanyi juga kemampuan mendengarkan nada atau notasi musik yang biasa disebut ear treaning, dan kemampuan membaca notasi musik yang disebut dengan sight reading (Last, 2012).

Sight reading berfungsi untuk meningkatkan kemampuan membaca dan menambah ilmu tentang bahasa musik. Tanpa bekal kemampuan tentang Solfegio tidak akan punya kemampuan bermain musik dengan baik (Husna, Mugi Nurul, Yudi Kusmayadi, 2016). Ketiga hal tersebut sangat penting dalam proses pembelajaran musik, begitu juga pembelajaran mata kuliah Instrumen Wajib Piano. Penerapan metode sight reading dalam pembelajaran instrumen piano bukanlah suatu hal yang baru, tetapi harus wajib dilakukan oleh orangorang atau para mahasiswa yang akan mengikuti ujian piano (Gunara, 2016).

Mata kuliah Instrumen Wajib Piano adalah salah satu mata kuliah praktik yang harus ditempuh seluruh mahasiswa Prodi Pendidikan Musik, Fakultas Seni Pertunjukan Institut Seni Indonesia Yogyakarta selain Instrumen pokok piano. Mata kuliah Instrumen Wajib Piano merupakan mata kuliah berjenjang yaitu Instrumen Wajib Piano I dan II. Mata kuliah tersebut masing-masing memiliki bobot 2 Satuan Kredit Semester (SKS). Oleh karena itu, jika Instrumen Wajib Piano I belum ditempuh, atau belum lulus, maka tidak diperbolehkan untuk menempuh Instrumen Wajib
Piano II. Mata kuliah ini untuk menunjang dalam pembelajaran ilmu-ulmu musik yang lain. Hal ini karena mata kuliah tersebut tidak hanya berhenti sampai Instrumen Wajib Piano I dan II. Mata kuliah ini masih berlanjut dengan mata kuliah Harmoni Manual I dan II. Mata kuliah Harmoni Manual ini diharapkan mahasiswa mampu mengimplementasikan akor-akor untuk mengiringi lagu pada instrumen piano. Oleh karena melalui pembelajaran mata kuliah Instrumen Wajib Piano ini, untuk mengembangkan rasa musikal para mahasiswa secara individu (Latifah, 2013). Selain itu mata kuliah ini diberikan di Prodi Pendidikan Musik agar para mahasiswa dapat menguasai dasardasar bermain instrumen piano dengan baik dan penjarian benar.

Mata kuliah Instrumen Wajib Piano I terdapat dalam paket sebaran kurikulum semester II, yang wajib ditempuh oleh semua mahasiswa semester II di Prodi Pendidikan Musik yang instrumen pokoknya selain piano. Namun demikian masih ada beberapa mahasiswa semester di atasnya yang belum lulus mengikuti bersamaan menempuh mata kuliah tersebut. Hal ini dikarenakan, beberapa mahasiswa ada yang jarang masuk kuliah presensi tidak memenuhi persyaratan $75 \%$ kehadiran sehingga tidak bisa mengikuti ujian. Selain itu ada juga mahasiswa yang belum siap materi untuk menempuh ujian, sehingga tidak lulus dan harus menempuh kuliah lagi bersama adik kelasnya.

Mahasiswa yang belum menempuh dan belum lulus mata kuliah Instrumen Wajib Piano, dikarenakan beberapa hal. Salah satu dari hal tersebut yang lebih banyak dialami mahasiswa Prodi Pendidikan Musik dari latar belakang yang berbeda. Hal ini dapat ditinjau dari Penerimaan Mahasiswa Baru (PMB) dengan 3 Jalur yaitu SNMPTN, SBMPTN dan Mandiri. Secara umum yang dari Jalur SNMPTN dan SBMPTN lebih banyak calon mahasiswa dari Sekolah Menengah Umum. Meskipun ada sebagian calon mahasiswa dari Sekolah Menengah Musik.

Pada umumnya mahasiswa dari Sekolah Menengah Umum, belum lancar dalam membaca notasi musik, bahkan ada yang sama sekali belum bisa membaca notasi musik. Notasi musik adalah simbol atau tanda untuk menyatakan 
tinggi rendahnya suara yang dilambangkan pada gambar (Rusdewanti, 2015). Oleh karena itu, sangat berpengaruh dalam proses pembelajaran Instrumen Wajib Piano, terutama perbedaan keterampilan dalam membaca notasi musik. Mahasiswa yang belum lancar bahkan belum bisa membaca notasi musik, maka akan mengalami kesulitan dan ketinggalan dengan mahasiswa yang sudah bisa membaca notasi musik. Hal tersebut, menjadi suatu permasalahan jika akan dilakukuan praktik secara individu. Indrawan mengatakan bahwa permasalahan pada perkuliahan individual instrumental tingkat tinggi untuk instrumentnstrumen melodis (Indrawan, A. 2015).

Mata kuliah Instrumen wajib piano ini, dianggap sebagai mata kuliah yang ditakuti atau menjadi momok bagi mahasiswa yang belum lancar, bahkan belum bisa dalam membaca notasi musik. Hal ini dikarenakan mahasiswa dituntut harus bisa memainkan instrumen piano dari materi yang diberikan, seperti; teknik, etude dan buah musik. Teknik memainkan instrumen piano memiliki teknik penjarian (fingering), teknik sentuhan (touching), teknik menggunakan pedal (pedaling) dan dengan memperhatikan dinamik (Aley, 2001). Oleh karena itu bermain piano harus memperhatikan letak nada dan teknik penjarian yang benar.

Teknik penjarian piano adalah suatu teknik tata cara kesesuaian membunyikan nada dengan penjarian dalam penekanan tuts piano. Mahasiswa yang menempuh mata kuliah Instrumen Wajib Piano I, selain harus lancar membaca notasi musik juga harus bisa memainkan instrumen piano minimal dengan teknik penjarian yang benar. Penggunaan penjarian yang benar merupakan aspek dasar terpenting dalam pembelajaran instrumen piano (Naenggolan, 2019). Berkaitan dengan hal tersebut, agar mahasiswa lebih terkontrol dalam praktik bermain piano dengan penjarian yang benar, maka proses pembelajaran Instrumen Wajib Piano I dalam satu kelas harus dibatasi jumlah mahasiswanya.

Pada umumnya mahasiswa Prodi pendidikan Musik yang menempuh mata kuliah Instrumen Wajib Piano I, setiap semester sekitar 40 hingga 50 mahasiswa. Mata kuliah tersebut biasanya diampu oleh 5 dosen. Maka dari itu, setiap dosen maksimal hanya 10 mahasiswa, agar pembelajaran lebih efektif. Pembelajaran yang efektif sangat mempengaruhi dalam meningkatkan hasil pembelajaran. Kegiatan pembelajaran yang efektif dan efiensi, merupakan dambaan bagi setiap pengajar. Oleh karena itu, dosen sebagai pengampu mata kuliah dituntut untuk dapat mengupayakan terciptanya kondisi proses pembelajaran yang efektif dan efisien (Rusdewanti, 2015).

Suatu pembelajaran yang kondusif dan efiensi, tentu saja juga harus didukung dengan perasaan yang bahagia dan senang, sehingga tidak terjadi kebosanan. Kegiatan atraktif dan inetraktif yang menyenangkan dapat menghilangkan kebosanan dan ketegangan dalam suasana yang monoton (Purnawan, 2000). Oleh karena itu, pembelajaran tersebut diperlukan suatu metode atau pendekatan yang sesuai dengan kondisi kelas. Pendekatan dan metode pembelajaran yang dilaksanakan oleh pemgampu mata kuliah, menguatkan kompetensi musikal dan mengembangkan kepiawaian mahasiswa dalam bermain piano (Latifah, 2012).

Seorang pengajar memberikan peranan penting dalam proses pembelajaran. Kegiatan pembelajaran agar dapat berhasil dengan baik, maka pengajar dituntut harus memahami dan menguasai berbagai ketrampilan yang dapat mendukung efektivitas dan efiensi kegiatan pembelajaran (Firmansyah, 2015). Meskipun segala cara dan upaya sudah dilakukan, namun belum tentu menjamin keberhasilan dalam proses pembelajran. Berhasil atau tidaknya suatu proses pembelajaran dapat dipengaruhi dari berbagai faktor, baik dari faktor intern maupun ekstren (Slameto, 2003). Hal ini juga terjadi pada proses pembelajaran Instrumen Wajib Piano I, yang dipengaruhi dari berbagai faktor. Pelaksanaan perkuliahan mata kuliah Instrumen Wajib Piano I, dilakukan secara klasikal dengan kelas kecil berjumlah sekitar 5 hingga 10 mahasiswa.

Pembelajaran Instrumen Wajib Piano I dilakukan dengan praktik bermain piano secara individu dan bergantian memainkan materi yang sudah diberikan sebelumnya. Oleh karena itu mahasiswa yang belum lancar, bahkan belum bisa dalam membaca notasi musik, dan belum siap untuk praktik, akan kelihatan pada waktu 
mahasiswa melakukan praktik bermain piano secara individu. Hal ini sering dijadikan alasan bagi mahasiswa, yang tidak siap untuk praktik, ijin tidak masuk kuliah, sehingga tidak sedikit mahasiswa yang belum lulus karena presensi kurang. Permasalahan ini selalu muncul setiap semester dalam pembelajaran Instrumen Wajib Piano I di Prodi Pendidikan Musik.

Berkaitan dengan permasalahan tersebut, maka untuk mengatasi proses pembelajaran Instrumen Wajib Piano I, diperlukan suatu solusi dan strategi atau metode pemebelajaran yang menyenangkan bagi mahasiswa. Metode pembelajaran adalah caracara dalam menyajikan materi pembelajaran yang dilakukan oleh pengajar pada peserta didiknya, agar terjadi proses pembelajaran yang tepat sebagai upaya untuk mencapai tujuan (Sutikno, 2009). Kemp menjelaskan bahwa strategi pembelajaran adalah suatu kegiatan pembelajaran yang harus dikerjakan oleh pengajar dan siswa agar tujuan pembelajaran dapat dicapai secara efektif dan efisien (Sanjaya, 2011). Sight singing merupakan solusi sebagai strategi pembelajaran, untuk membantu proses pembelajaran praktik mata kuliah Instrumen Wajib Piano I.

Penerapan Sight singing (menyanyi) dalam proses pembelajaran mata kuliah Instrumen Wajib Piano I diharapkan dapat membuat mahasiswa merasa lebih senang. Dalam proses pembelajaran diperlukan suasana yang kondusif, nyaman dan senang. Hal ini untuk memberikan motivasi yang tinggi dalam proses pembelajaran. Motivasi memegang peranan penting dalam memberikan gairah, semangat dan rasa senang (Purnawan, 2000). Lebih lanjut Wadiyo mengatakan bahwa kesenangan itu bisa dipadukan dengan akal pikiran dan dituangkan dalam bentuk nyanyian (Utomo, 2018). Selanjutnya Sularmono juga menjelaskan bahwa sight singing salah satu dari metode Solfegio memberikan stimulus yang menyenangkan sehingga terjadi perubahan pengalaman belajar (Sulasmono, 2013). Hal ini dilakukan sebagai upaya pengajar untuk menyajikan materi yang menarik, agar meningkatkan proses pembelajaran Instrumen Wajib Piano I dengan baik. Gaya penyajian yang dilakukan seorang pengajar dalam membahas suatu materi, sangat berpengaruh terhadap perhatian peserta didiknya. Penyampaian materi ajar hendaknya disajikan dengan cara yang lebih menarik dan menyenangkan, sehingga rasa ingin tahu dari peserta didik terhadap materi pelajaran akan meningkat (Sumiati, 2009). Penelitian ini terfokus untuk melihat proses dan penerapan sight singing dalam pembelajaran Instrumen Wajib Piano I di Prodi Pendidikan Musik.

\section{Metode Penelitian}

Metode yang digunakan dalam penelitian ini adalah metode Penelitian Tindakan Kelas dengan memanfaatkan data kualitatif. Penelitian Tindakan Kelas (Classrom Action Research) merupakan sebuah kegiatan yang dilaksanakan untuk mengamati kejadian dalam kelas untuk memperbaiki praktik dalam proses pembelajaran agar lebih berkualitas, sehingga hasil pembelajaran menjadi lebih baik (Djamarah, 2012). Selanjutnya Mulyatiningsih menjelaskan bahwa Penelitian Tindakan (action research) termasuk dalam ruang lingkup penelitian terapan (applied research) yang menggabungkan antara pengetahuan, penelitian dan tindakan.

Penelitian Tindakan Kelas (PTK) memiliki peran yang sangat penting dan strategis dalam upaya meningkatkan kualitas proses pembelajaran. Oleh karena itu, Penelitian Tindakan Kelas (PTK) merupakan salah satu cara yang ditempuh pengajar untuk meningkatkan kualitas pembelajaran. Secara garis besar terdapat empat tahapan yang lazim dilalui dalam PTK yaitu: perencanaan, pelaksanaan, pengamatan, dan refleksi. Keempat tahapan tersebut merupakan tahapan-tahapan yang membentuk sebuah siklus; dengan demikian, PTK bukan merupakan kegiatan tunggal, akan tetapi selalu berupa serangkaian kegiatan yang akan kembali ke asal dalam bentuk siklus-siklus. Penelitian Tindakan Kelas cukup menggunakan satu kelas, tetapi tindakan yang dilakukan dapat berulang-ulang sampai menghasilkan perubahan menuju ke arah perbaikan. Pengulangan langkah dari setiap awal sampai akhir seperti disebut siklus. Pengulangan langkah dalam PTK sebaiknya dilaksanakan paling tidak dua siklus. Penelitian tindakan jarang ada keberhasilan yang dapat dicapai dalam satu kali tindakan, maka dari itu, 
PTK sering dilakukan dalam beberapa siklus tindakan (O’Brien, 2001).

Penelitian Tindakan Kelas dapat dikategorikan sebagai penelitian kualitatif-eksperimen; karena analisis datanya menggunakan pendekatan kualitatif, dan ada tindakan yang dikenakan terhadap subjek penelitian, serta dilakukan analisis dan evaluasi terhadap hasil yang dicapai setelah dilakukan tindakan. Tujuan yang paling utama dalam PTK adalah untuk memecahkan permasalahan nyata yang terjadi di dalam kelas sekaligus mencari jawaban ilmiah mengapa hal tersebut dapat dipecahkan melalui tindakan yang akan dilakukan. Selain itu juga untuk meningkatkan kegiatan nyata pengajar dalam pengembangan profesinya.

Tujuan Penelitian Tindakan Kelas adalah untuk memperbaiki kualitas proses pembelajaran. Oleh karena itu, kegiatan yang dilakukan haruslah berupa tindakan yang diyakini akan lebih baik dari kegiatan-kegiatan yang sudah dilakukan. Dengan kata lain, tindakan yang akan diberikan kepada murid harus terlihat lebih efektif, efisien, kreatif dan inovatif. Selain itu juga, hal yang berbeda dari yang sudah dilakukan pengajar dalam praktik pembelajaran sebelumnya, karena yang sudah dilakukan dipandang belum memberikan hasil yang memuaskan. Hal ini seperti yang dijelaskan oleh Rahdiyanto bahwa tujuan PTK adalah untuk mengatasi berbagai persoalan nyata guna memperbaiki atau meningkatkan kualitas proses pembelajaran di kelas (Rahdiyanto, 2012).

Penelitian Tindakan Kelas ini, dilakukan untuk mendeskripsikan proses pembelajaran mata kuliah Instrumen Wajib Piano I dengan penerapan sight singing sebagai upaya peningkatan minat belajar para mahasiswa. Penggunaan metode PTK ini didasarkan pada permasalahan yang dihadapi pada materi kuliah terutama etude, sonatine dan buah musik atau lagu dari sebagian besar mahasiswa yang kurang lancar dalam membaca notasi.

\section{Proses Pembelajaran Instrumen Piano}

Proses pembelajaran mata kuliah Instrumen wajib Piano I di Prodi Pendidikan Musik dilakukan melalui tiga tahap. Tahapan dalam pembelajaran mata kuliah tersebut adalah perencanaan, pelaksanaan dan evalusi akhir. Tahapan ini dilakukan agar proses pembelajaran dapat berjalan secara baik, lancar dan sistematis.

a. Tahap Perencanaan

Perencanaan merupakan suatu proses penyusunan sesuatu yang akan dilaksanakan untuk mencapai tujuan yang telah ditentukan. Perencanaan tersebut dapat disusun berdasarkan kebutuhan dalam jangka tertentu sesuai dengan keinginan pembuat perencanaan. Perencanaan adalah suatu langkah antisipatif dalam proses penyusunan materi pembelajaran secara sistematis dan terintegrasi (Fitri, Eka Annisa, Sri Saparahayuningsih, 2013). Pada umumnya seorang pengajar dituntut untuk merencanakan apa yang akan dilakukan dalam pengelolaan kegiatan proses pembelajaran dalam satu semester (Susilowati, 2018). Dalam membuat perencanaan pembelajaran harus dapat menyusun berbagai program pengajaran sesuai pendekatan dan metode yang akan digunakan. Akan tetapi perencanaan yang dibuat harus dapat dilaksanakan dengan mudah dan tepat sasaran. Pembelajaran akan lebih optimal apabila seorang pengajar terlebih dahulu mempersiapkan perencanaan pembelajaran (Nadzir, 2013).

Pada tahapan perencanaan diawali dengan menyusun perangkat pembelajaran mata kuliah instrumen wajib piano I yaitu silabus, Rencana Pembelajaran Semester (RPS) dan kontrak kuliah. Perencanaan perangkat pembelajaran mata kuliah Instrumen Wajib Piano I tentunya yang akan diberikan dalam satu semester. Oleh karena itu, penyusunan RPS mata kuliah tersebut didasarkan pada silabus dan kondisi pembelajaran agar kegiatan pembelajaran dapat berjalan sesuai yang diharapkan. Setelah melakukan persiapan sebagai perencanaan kuliah, kemudian melakukan pelaksanaan proses pembelajaran.

b. Tahap Pelaksanaan

Tahap pelaksanaan proses pembelajaran ini merupakan tahap implementasi atau penerapan atas desain perencanaan mata kuliah Instrumen Wajib Piano I yang telah dibuat oleh pengajar. Hakikat dari tahap 
pelaksanaan adalah kegiatan operasional pembelajaran mata kuliah Instrumen Wajib Piano I itu sendiri. Dalam tahap ini, pengajar melakukan interaksi proses pembelajaran melalui penerapan berbagai strategi metode dan teknik pembelajaran, serta pemanfaatan seperangkat media yang akan digunakan. Pada pelaksanaan perkuliahan mata kuliah Instrumen Wajib Piano I, sebelum diberikan materi bahan ajar diawali dengan pengantar kuliah yang berisi penyampaian kontrak kuliah, dan materi kuliah Instrumen Wajib Piano I dalam satu semester yang tertuang dalam Rencana Pembelajaran Semester (RPS). Kontrak kuliah berisi tentang perjanjian pelaksanaan perkuliahan yang dibuat dan disetujui bersama oleh dosen dan mahasiswa sebagai pedoman bersama. Rencana Pembelajaran Semester (RPS) berisi tentang penjabaran pokok bahasan dari materi ajar yang akan diberikan dalam satu semester selama 1216 pertemuan.

Materi mata kuliah Instrumen Wajib Piano I yang akan diberikan dalam satu semester berisi tentang teknik, etude, sonatine, dan buah musik (lagu). Materi teknik berupa tangga nada, trinada dan kadens baik tangga nada mayor maupun minor. Materi teknik menggunakan buku tangga nada dan trinada yang dibuat oleh Latifah Kodijat. Kemudian materi etude, menggunakan buku Beyer, Op. 101, buku 50 Kleine Etuden dari J.C Beuk dan buku Duvernoy, Op. 176 dari Ecole Primaire. Etude adalah suatu komposisi musik yang dipersiapkan dengan tujuan untuk melatih keterampilan bermain alat musik. Etude yang diberikan terdiri dari etude teknik yang bertujuan untuk mengembangkan keterampilan jari dan etude melodi yang bertujuan melatih tanda-tanda ekspresi, artikulasi serta melatih interpretasi (Banoe, 2003). Selanjutnya untuk materi sonatine berupa melodi beserta akornya, menggunakan buku sonatine dari Oscar Bolck, Op. 30 dan buku sonatinen dari J.B. Wanhal, Op. 41. Materi selanjutnya yaitu buah musik berupa lagu, menggunakan buku yang berjudul “Teacher's Choice for the Young Pianist".

Pembelajaran mata kuliah Instrumen Wajib Piano I dilakukan secara kelompok dan individu. Setiap semester mata kuliah tersebut dalam satu kelas kurang lebih 10 mahasiswa.

Proses pelaksanaan dalam pembelajaran Instrumen Piano I, diawali dengan materi teknik berupa tangga nada, trinada dan kadens I-IVV-I. Kadens merupakan progres akor sebagai pengakhiran akor dasar pada lagu (Akbari, 2018). Tangga nada dan trinada yang diberikan pada mata kuliah Instrumen Piano I yaitu tangga nada mayor C, G, F dan minor A, E, $\mathrm{D}$ yang harus dimainkan 3 oktaf naik turun. Tenik trinada ini dimainkan secara arpeggio yaitu memainkan nada-nada pada akor dengan berurutan dan bergantian. Untuk memainkan teknik tersebut para mahasiswa dituntut harus dengan penjarian yang benar, baik tangga nada, trinada ataupun kadens. Materi teknik ini diberikan sebagai dasar untuk bermain piano dengan penjarian yang benar dan melatih kelenturan otot-otot jari tangan. Namun untuk memainkan teknik dengan penjarian yang benar diperlukan waktu yang panjang. Oleh karena itu materi bahan ajar yang berisi teknik, etude, sonatine dan buah lagu tersebut membutuhkan waktu beberapa pertemuan dalam satu semester.

Penjarian atau fingering merupakan istilah penomoran jari untuk bermain instrumen piano. Dalam pembelajaran mata kuliah Instrumen Wajib Piano I, untuk penjarian merujuk pada penggunaan jari yang baik dan benar dalam bermain piano. Penjarian yang baik dan benar merupakan aspek terpenting dalam pembelajaran mata kuliah Instrumen Wajib Piano I. Oleh karena itu materi tentang penjarian harus diberikan sejak awal pertemuan pada pembelajaran Instrumen Wajib Piano I, terutama pada materi teknik. Penggunaan penjarian dalam pembelajaran Instrumen Wajib Piano I, memiliki tujuan untuk menolong agar bermain piano dapat memainkan piano dengan mudah dan tanpa memerlukan

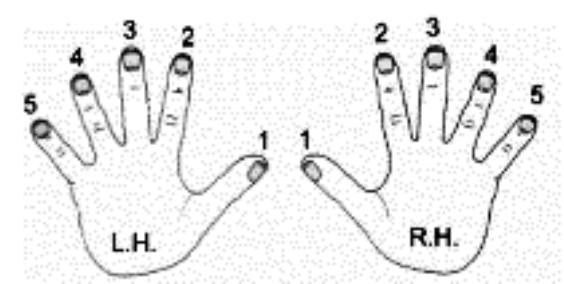

Gambar 1: Penomoran jari pada tangan. 
tenaga yang berlebihan (Mulyono, 2008). Dalam artian penjarian ini digunakan untuk membentuk efisiensi dan efektivitas dalam bermain piano (Kodijat, 2008). Penjarian dalam bermain piano dilakukan berdasarkan urutan jari, baik pada tangan kanan maupun kiri. Terdapat lima nomor pada penjarian piano, yaitu: jempol (1), telunjuk (2), jari tengah (3), jari manis (4), dan kelingking (5). Gambar 1 merupakan gambar penomeran jari pada tangan kanan dan kiri.

Materi ajar yang berupa teknik, etude, Sonatine dan buah lagu dalam proses pembelajaran mata kuliah Instrumen Wajib Piano I pada semester Genap tahun ajaran 2018-2019 di Prodi Pendidikan Musik, diperlukan suatu tahapan pertemuan dalam perkuliahan selama satu semester. Adapun tahapantahapan pelaksanaan perkuliahan tersebut dapat dirinci sebagai berikut.

\section{Pertemuan pertama}

Pada pertemuan pertama ini, sebelum masuk materi ajar diberikan pengantar sebagai pendahuluan dengan perkenalan baik dosen maupun mahasiswa yang mengambil mata kuliah Instrumen Wajib Piano I. Selain itu diberikan tentang kontrak kuliah sebagai acuan kesepakatan proses pembelajaran dalam satu semester. Kemudian yang lebih penting diberikan informasi tentang silabus, dan Rencana Pembelajaran Semester (RPS) berisi materi mata kuliah Instrumen Wajib Piano I yang akan diberikan dalam satu semester.

Selanjutnya untuk mengawali perkuliahan Instrumen Wajib Piano I diberikan materi sebagai bahan persiapan pertemuan berikutnya. Materi tersebut berisi teknik yaitu tangga nada, trinada, dan kadens dari tangga nada $\mathrm{C}$ mayor dan A minor. Tangga nada $\mathrm{C}$ mayor dan A minor yang dimainkan dalam 3 okttaf searah naik turun dengan penjarian yang benar. Berikut contoh susunan notasi dan penjarian yang benar pada tangga nada $\mathrm{C}$ mayor dan A minor yang harus dimainkan oleh mahasiswa.

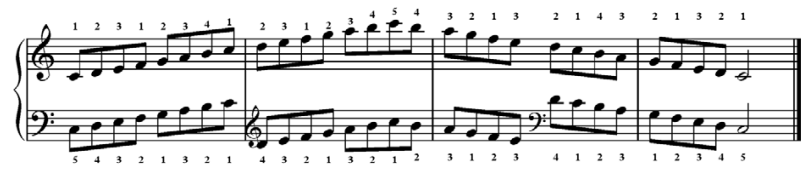

Notasi 1: Susunan dan penjarian tangga nada $\mathrm{C}$ mayor.

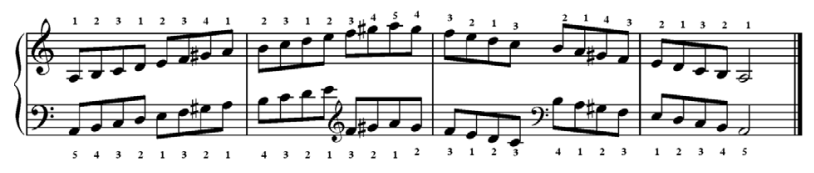

Notasi 2: Susunan dan penjarian tangga nada A minor.

Materi selanjutnya yaitu trinada dari tangga nada $\mathrm{C}$ mayor dan $\mathrm{A}$ minor yang dimainkan dalam 3 oktaf naik turun secara arpeggio dengan penjarian yang benar. Berikut contoh susunan notasi dan penjarian yang benar dari trinada $\mathrm{C}$ mayor dan A minor.

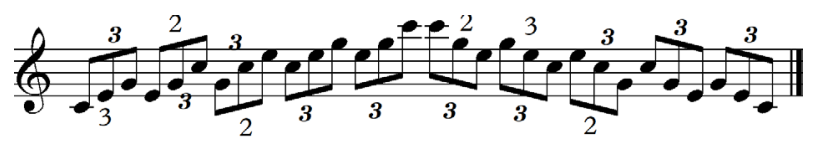

Notasi 3: Susunan dan penjarian trinada dari tangga nada $\mathrm{C}$ mayor.

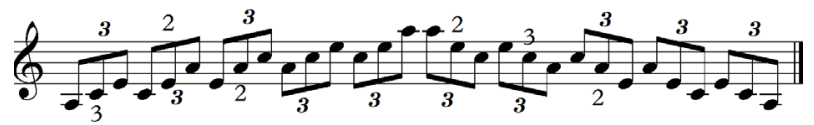

Notasi 4: Susunan dan penjarian trinada dari tangga nada A Minor.

Materi selanjutnya adalah kadens dari tangga nada $\mathrm{C}$ mayor dan A minor yang dimainkan dengan progres akor I-IV-V-I. Akor I-IV-V-I dari tangga nada $\mathrm{C}$ mayor adalah C-FG-C dan akor I-IV-V-I dari tangga nada A minor adalah Am-Dm-E-Am. Berikut contoh susunan notasi kadens atau progres akor dari tangga nada $\mathrm{C}$ mayor dan A minor.

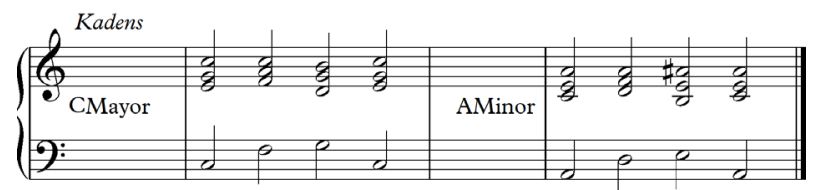

Notasi 5: Susunan kadens dari tangga nada C mayor dan A minor.

2. Pertemuan kedua

Pada pertemuan ini, mahasiswa diminta untuk mempraktikkan materi yang sudah diberikan pada minggu sebelumnya yaitu memainkan instrumen piano dengan tangga nada, trinada, dan kadens dari tangga nada C mayor dan A minor. Proses pembelajaran Instrumen Wajib Piano I, dalam praktik bermain piano dilakukan secara kelompok dan individu. Praktik bermain piano dimulai dari tangga nada $\mathrm{C}$ mayor dan $\mathrm{A}$ minor terlebih dahulu. Setelah memainkan tangga nada dengan lancar dilanjutkan trinadanya. Kemudian setelah 
keduanya dapat bermain lancar disambung dengan kadens atau progres akornya. Berikut gambar mahasiswa yang praktik bermain piano secara kelompok dan Individu, pada materi teknik dari tangga nada, trinada dan kadens $\mathrm{C}$ mayor dan A minor.

3. Pertemuan ketiga

Pada pertemuan ketiga ini, mengulang materi dari pertemuan kedua, kemudian dilanjutkan dengan materi baru yaitu tangga nada, trinada, dan kadens dari $G$ mayor dan $E$ minor. Tangga nada $\mathrm{G}$ mayor dan $\mathrm{E}$ minor yang dimainkan dalam 3 okttaf searah naik turun dengan penjarian yang benar. Berikut contoh susunan notasi dan penjarian yang benar pada tangga nada $\mathrm{G}$ mayor dan $\mathrm{E}$ minor yang harus dimainkan oleh mahasiswa.

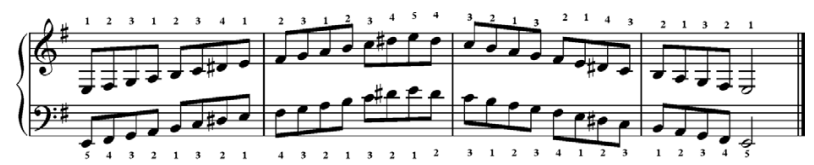

Notasi 6: Susunan dan penjarian tangga nada G mayor.

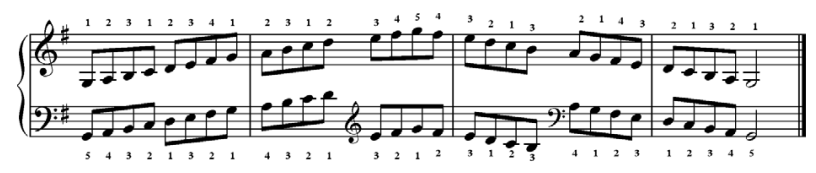

Notasi 7: Susunan dan penjarian tangga nada E minor.

Materi selanjutnya adalah trinada dari tangga nada $G$ mayor dan E minor yang dimainkan dalam 3 oktaf naik turun secara arpeggio dengan penjarian yang benar. Berikut contoh susunan notasi dan penjarian yang benar pada trinada $G$ mayor dan E minor.

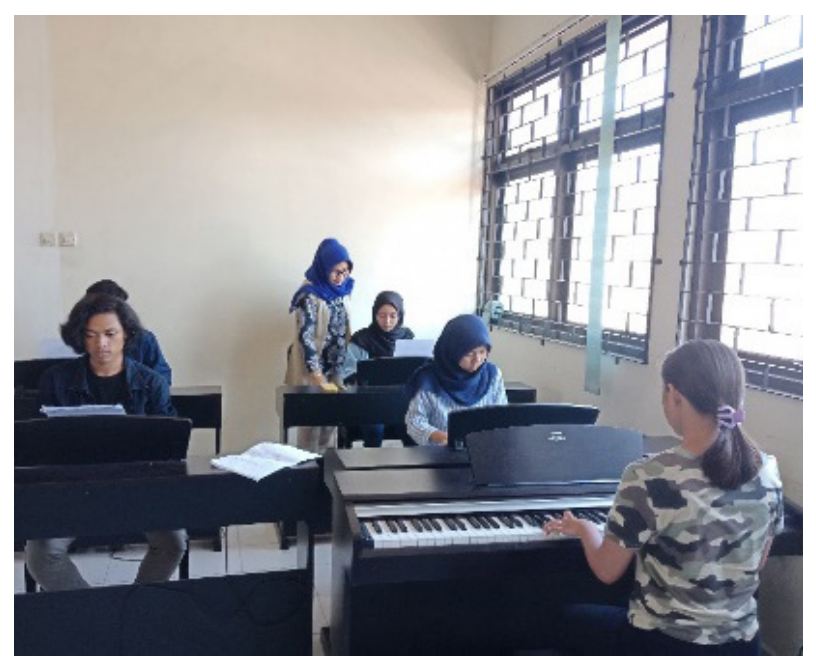

Gambar 2: Foto Proses pembelajaran Instrumen Wajib Piano I secara kelompok.

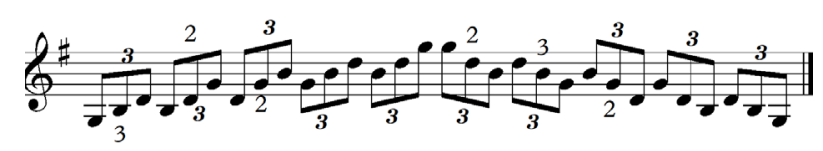

Notasi 8: Susunan dan penjarian trinada dari tangga nada G mayor.

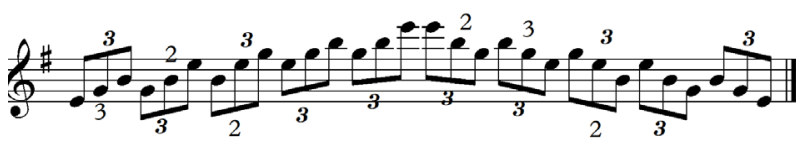

Notasi 9: Susunan dan penjarian trinada dari tangga nada E Minor.

Materi selanjutnya yaitu kadens dari tangga nada $G$ mayor dan $E$ minor yang dimainkan dengan progres akor I-IV-V-I. Akor I-IV-V-I dari tangga nada $\mathrm{G}$ mayor adalah G-C-D-G dan akor I-IV-V-I dari tangga nada $\mathrm{E}$ minor adalah Em-Am-B-Em. Berikut contoh susunan notasi kadens atau progres akor dari tangga nada $\mathrm{G}$ mayor dan $\mathrm{E}$ minor yang harus dimainkan oleh mahasiswa.

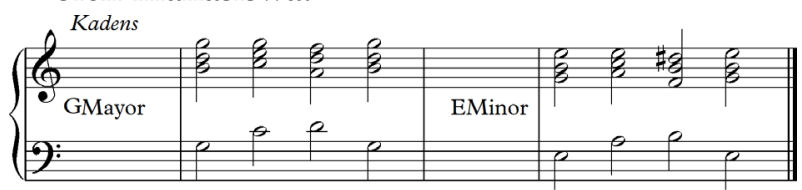

Notasi 10: Susunan kadens dari tangga nada G mayor dan E minor.

4. Pertemuan keempat

Pada pertemuan keempat ini, mengulang materi pertemuan sebelumnya, mahasiswa diminta untuk mempraktikkan bermain piano pada materi tangga nada, trinada, dan kadens dari tangga nada G mayor dan E minor. Materi tersebut harus dimainkan secara lancar dan penjarian yang benar. Proses pembelajaran Instrumen Wajib Piano I pada materi tersebut, dalam praktik

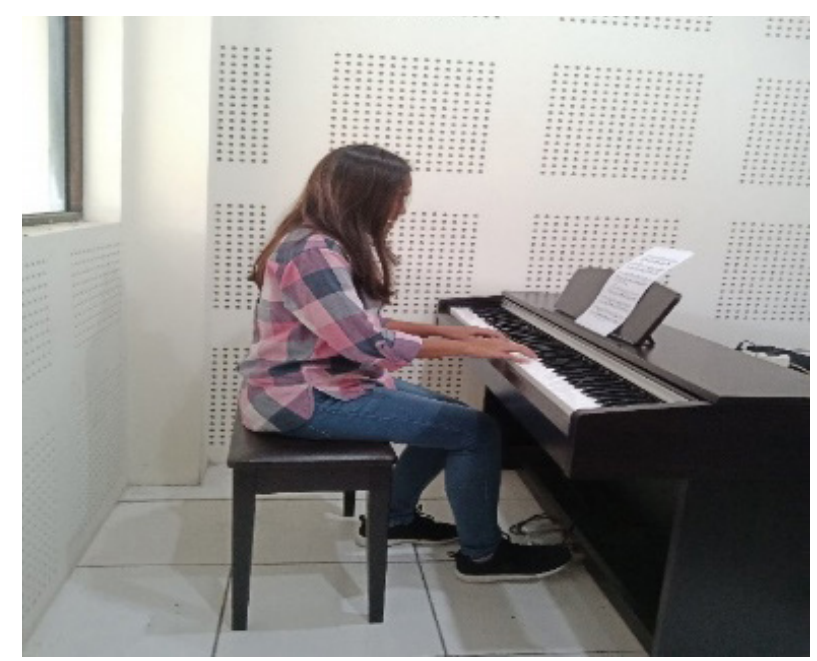

Gambar 3: Foto Proses pembelajaran Instrumen Wajib Piano I secara individu. 
bermain piano dilakukan secara kelompok dan individu. Dalam praktik bermain piano dimulai secara kelompok terlebih dahulu, kemudian bermain individu, agar lebih terkontrol. Adapun materi yang harus dimainkan dari tangga nada G mayor dan E minor terlebih dahulu. Setelah memainkan tangga nada dengan lancar dilanjutkan trinadanya. Kemudian setelah keduanya dapat dimainkan dengan lancar dilanjutkan materi kadens atau progres akor I-IV-V-I.

Selanjutnya setelah semua mahasiswa melakukan praktik bermain piano secara individu dengan lancar, kemudian diberikan materi baru. Materi baru ini untuk dipersiapkan sebagai bahan pertemuan berikutnya. Materi tersebut yaitu tangga nada, trinada, dan kadens dari tangga nada $\mathrm{F}$ mayor dan $\mathrm{D}$ minor. Tangga nada $\mathrm{F}$ mayor dan $\mathrm{D}$ minor yang dimainkan dalam 3 okttaf searah naik turun dengan penjarian yang benar. Berikut contoh susunan notasi dan penjarian yang benar pada tangga nada $\mathrm{F}$ mayor dan $\mathrm{D}$ minor yang harus dimainkan oleh mahasiswa.

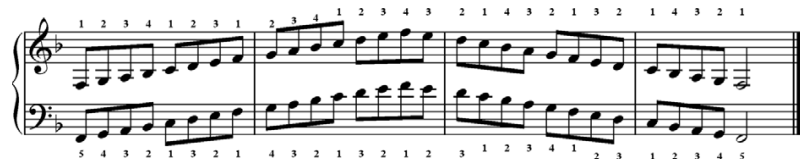

Notasi 11: Susunan dan penjarian tangga nada F mayor.

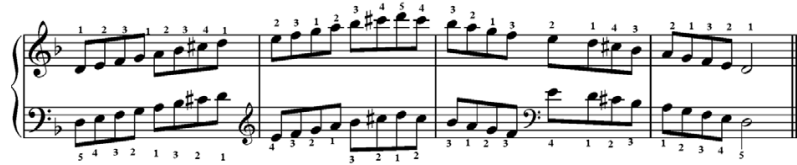

Notasi 12: Susunan dan penjarian tangga nada D minor.

Materi selanjutnya yaitu trinada dari tangga nada $\mathrm{F}$ mayor dan $\mathrm{D}$ minor yang dimainkan dalam 3 oktaf naik turun secara arpeggio dengan penjarian yang benar. Berikut contoh susunan notasi dan penjarian yang benar pada trinada $\mathrm{F}$ mayor dan $\mathrm{D}$ minor.

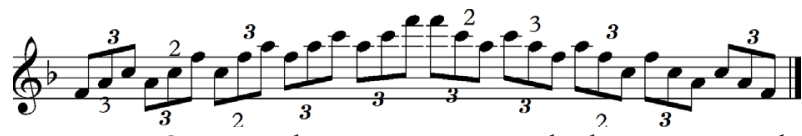

Notasi 13: Susunan dan penjarian trinada dari tangga nada F mayor.

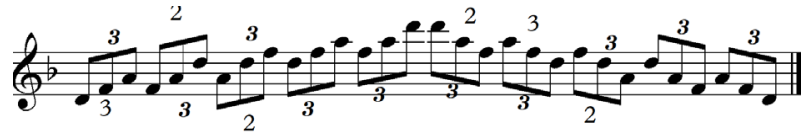

Notasi 14: Susunan dan penjarian trinada dari tangga nada D Minor.
Materi selanjutnya adalah kadens dari tangga nada $\mathrm{F}$ mayor dan $\mathrm{D}$ minor yang dimainkan dengan progres akor I-IV-V-I. Akor I-IV-V-I dari tangga nada $F$ mayor adalah F-BC-F dan akor I-IV-V-I dari tangga nada D minor adalah Dm-Gm-A-Dm. Berikut contoh susunan notasi kadens yang benar pada $\mathrm{F}$ mayor dan $\mathrm{D}$ minor.

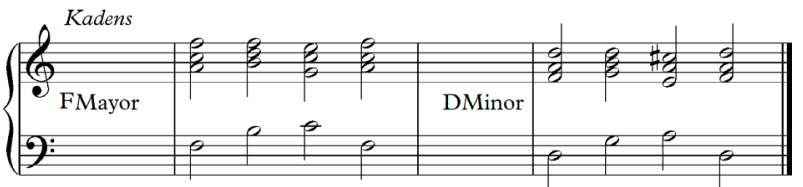

Notasi 15: Susunan kadens dari tangga nada F mayor dan D minor.

\section{Pertemuan kelima}

Pada pertemuan ini, mengulang materi sebelumnya, mahasiswa diminta untuk mempraktikkan bermain piano secara individu. Mahasiswa secara bergantian praktik satu persatu, agar lebih mudah dalam mengontrol penjariannya. Materi yang harus dimainkan yaitu semua tangga nada, trinada dan kadens dari C, G dan F mayor serta tangga nada, trinada dan kadens dari A, E dan D minor. Materi tersebut harus dimainkan dengan lancar dan penjarian yang benar. Setelah semua mahasiswa dapat memainkan teknik tersebut dengan lancar kemudian diberikan materi baru yaitu etude, sebagai bahan pertemuan berikutnya. Hal ini dilakukan karena teknik sebagai dasar penjarian yang benar untuk memainkan materi etude dan materi selanjutnya.

6. Pertemuan keenam

Pada pertemuan ini diberikan materi dari salah satu etude buku Beyer, Op. 101, Nomor 58 dan 59. Mahasiswa dituntut harus bisa memainkan piano dengan lancar dan penjarian yang benar. Oleh karena itu pada materi ini, jika kurang lancar atau belum bisa membaca notasi musik akan mengalami kesulitan dalam mengikuti perkuliahan.

Pada materi ini, tangan kanan untuk memainkan melodi dan tangan kiri untuk memainkan akor. Proses pembelajarannya, sebelum memainkan melodi pada tangan kanan para mahasiswa diminta untuk membaca dan menyanyikan notasi melodi dengan solmisasi 
terlebih dahulu. Setelah bisa membaca dan menyanyikan melodi dengan lancar kemudian mempraktikkan bermain piano dengan tangan kanan dan penjarian yang benar. Selanjutnya memainkan akor pada tangan kiri dengan lancar dan penjarian yang benar. Setelah bisa memainkan dengan melodi tangan kanan dan akor tangan kiri secara lancar kemudian dilanjutkan mempraktikkan bermain piano dengan tangan kanan dan kiri secara bersamasama.

7. Pertemuan ketujuh

Pada pertemuan ini mengulang materi sebelumnya agar lebih lancar, kemudian dilanjutkan materi etude baru dari buku 50 Kleine Etuden dari J.C Beuk Nomor 43. Materi ini hampir sama dengan etude dari Beyer, yaitu tangan kanan untuk memainkan melodi dan tangan kiri untuk memainkan akor. Proses pembelajarannya juga sama, memainkan melodi pada tangan kanan terlebih dahulu dengan lancar dan penjarian yang benar. Kemudian memainkan akor pada tangan kiri dengan lancar dan penjarian yang benar. Selanjutnya memainkan melodi dan akor secara bersamasama tangan kanan dan kiri. Oleh karena itu mahasiswa dituntut harus lancar membaca notasi musik, agar lebih mudah untuk mengikuti proses pembelajaran Instrumen Wajib Piano I.

8. Pertemuan kedelapan

Pada pertemuan ini mengulang materi sebelumnya kemudian dilanjutkan materi baru dari buku Duvernoy, Op. 176 dari Ecole Primaire Nomor 3. Materi ini juga termasuk salah satu etude, bentuknya juga sama seperti etude yang lain yaitu tangan kanan untuk memainkan melodi dan tangan kiri untuk memainkan akor. Proses pembelajarannya sama seperti sebelumnya, para mahasiswa diminta untuk membaca dan menyanyikan notasi melodi dengan solmisasi terlebih dahulu. Setelah bisa membaca dan menyanyikan dengan lancar kemudian dipraktikan bermain piano dengan tangan kanan dan penjarian yang benar. Selanjutnya memainkan akor pada tangan kiri, kemudian dimainkan secara bersama-sama tangan kanan dan kiri.

\section{Pertemuan kesembilan}

Pada pertemuan ini mengulang materi sebelumnya, untuk mengecek kelancaran materi dari etude, kemudian dilanjutkan materi baru dari buku sonatine dari Oscar Bolck, Op. 30. Untuk Materi Instrumen wajib Piano I, bisa memainkan sonatine I bagian 1, 2 dan 3 atau sonatine II bagian 1, 2 dan 3. Materi ini bentuknya juga sama seperti etude yang lain yaitu tangan kanan untuk memainkan melodi dan tangan kiri untuk memainkan akor. Proses pembelajaran atau latihannya juga sama seperti sebelumnya yaitu mendahulukan tangan kanan untuk melodi dan tangan kiri untuk akor, kemudian dimainkan secara bersama.

10. Pertemuan kesepuluh

Pada pertemuan ini mengulang materi sebelumnya yaitu sonatine I bagian 1, 2 dan 3 atau sonatine II bagian 1, 2 dan 3. Kemudian dilanjutkan materi baru dari buku sonatinen dari J.B. Wanhal, Op. 41. Materi ini terdiri dari dua bagian, tetapi mahasiswa boleh memilih hanya satu bagian saja. Bentuk materi ini juga sama dengan yang lain, tangan kanan untuk memainkan melodi dan tangan kiri untuk memainkan akor. Proses pembelajaran atau latihannya juga sama seperti sebelumnya, para mahasiswa diminta untuk membaca dan menyanyikan notasi melodi dengan solmisasi terlebih dahulu. Setelah bisa membaca dan menyanyikan dengan lancar kemudian dipraktikan bermain piano dengan melodi pada tangan kanan dan penjarian yang benar. Selanjutnya memainkan akor pada tangan kiri dengan penjarian yang benar, kemudian dimainkan secara bersama-sama melodi pada tangan kanan dan akor pada tangan kiri.

11. Pertemuan kesebelas

Pada pertemuan ini mengulang materi sebelumnya, untuk mengecek materi sonatine agar lebih lancar. Setelah bisa memainkan materi sonatine dengan lancar, kemudian dilanjutkan materi baru. Materi baru berupa buah musik atau lagu yang diambil dari buku "Teacher's Choice for the Young Pianist", yang berjudul "LULLABY". Bentuk materi lagu ini juga sama dengan materi sebelumnya, 
hanya saja lebih melodis. Dalam praktiknya tangan kanan untuk memainkan melodi dan tangan kiri untuk memainkan akor. Proses pembelajaran atau latihannya juga sama seperti sebelumnya. Prosesnya dimulai dengan membaca dan menyanyikan notasi melodi dengan solmisasi terlebih dahulu. Setelah lancar kemudian dipraktikkan bermain piano dengan melodi pada tangan kanan dan dengan penjarian yang benar. Selanjutnya memainkan akor pada tangan kiri dengan penjarian yang benar, kemudian dimainkan secara bersamasama melodi pada tangan kanan dan akor pada tangan kiri.

12. Pertemuan keduabelas

Pada pertemuan ini mengulang materi sebelumnya, kemudian dilanjutkan materi baru yang berupa buah musik atau lagu dari buku "Teacher's Choice for the Young Pianist", yang berjudul "Walts From Coppellia". Bentuk materi lagu ini juga sama tangan kanan untuk memainkan melodi dan tangan kiri untuk memainkan akor. Proses pembelajaran atau latihannya juga sama seperti etude dan sonatine.

13. Pertemuan ketigabelas

Pada pertemuan ini mengulang semua materi etude dari buku Beyer, Op. 101, Nomor 58 dan 59, buku 50 Kleine Etuden dari J.C Beuk Nomor 43 dan Duvernoy, Op. 176 dari Ecole Primaire Nomor 3. Hal ini dilakukan untuk pengambilan nilai materi etude, sekaligus Checking terakhir, baik ketepatan tempo, dinamik, kelancaran dalam bermain piano maupun penjarian yang benar. Selain itu juga untuk mempersiapkan bahan ujian akhir semester.

\section{Pertemuan keempatbelas}

Pada pertemuan ini mengulang semua materi teknik tangga nada, trinda dan kadens, kemudian sonatine dari Oscar Bolck, Op. 30, dan sonatinen dari J.B. Wanhal, Op. 41. Hal ini dilakukan untuk pengambilan nilai materi teknik dan sonatine, sekaligus Checking terakhir baik ketepatan tempo, dinamik, kelancaran dalam bermain piano maupun penjarian yang benar. Selain itu juga untuk mempersiapkan bahan ujian akhir semester.
15. Pertemuan kelimabelas

Pada pertemuan kelima belas ini, mengulang materi buah musik atau lagu yang berjudul "LULLABY" dan "Walts From Coppellia" diambil dari buku "Teacher's Choice for the Young Pianist",. Hal ini dilakukan untuk pengambilan nilai materi lagu dan sekaligus Checking terakhir baik ketepatan tempo, dinamik, kelancaran dalam bermain piano maupun penjarian yang benar. Selain itu juga untuk mempersiapkan bahan ujian akhir semester.

Pada umumnya dalam satu semester terdiri dari enam belas pertemuan atau tatap muka. Oleh karena itu masih ada cadangan satu pertemuan, yang biasanya diberikan untuk latihan secara mandiri. Kesempatan ini diberikan, agar para mahasiswa bisa mempersiapkan materi lebih memperdalam untuk menghadapi ujian akhir semester.

\section{Penerapan Sight Singing dalam Pembelajaran Instrumen Piano}

Pembelajaran mata kuliah Instrumen Wajib Piano I, yang banyak mengalami hambatan dalam membaca notasi musik, terutama pada materi etude, sonatine dan buah musik atau lagu. $\mathrm{Hal}$ ini karena dalam memainkan piano harus terbagi antara membaca notasi dan penjarian yang benar. Oleh karena itu, untuk mengatasi hal tersebut, diperlukan suatu strategi untuk meningkatkan pembelajaran mata kuliah Instrumen Wajib Piano I. Strategi yang dilakukan dalam proses pembelajaran

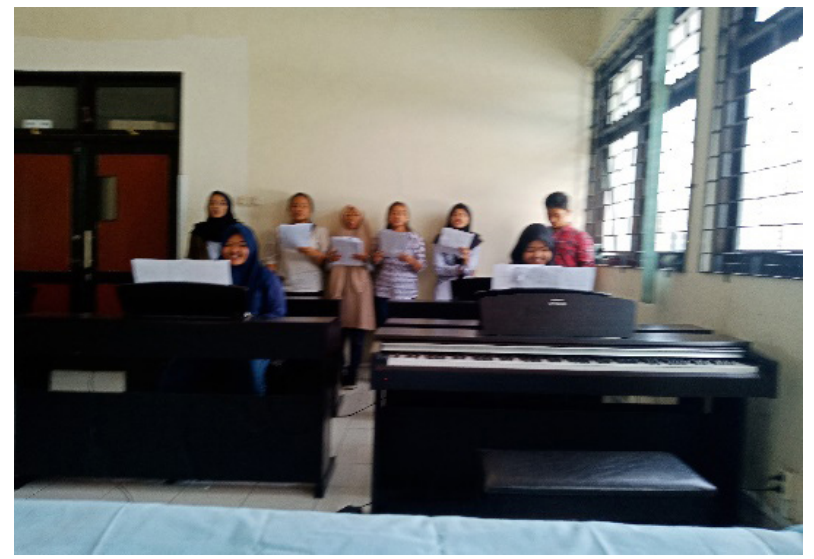

Gambar 4: Foto Penerapan sight singing pada materi etude dari Beyer, Op. 101, No. 58. 
Instrumen Wajib Piano I dengan menerapkan metode sight singing menyanyi). Penerapan sight singing pertama kali dilakukan untuk materi etude, sonatine dan buah muasik atau lagu.

Dalam proses pembelajaran Instrumen Wajib Piano I, terutama materi etude, sonatine dan buah muasik atau lagu. diawali dengan sight reading (membaca) dan sight singing (menyanyi) notasi melodi pada etude baik secara kelompok maupun individu. Sight reading (membaca) dan sight singing (menyanyi), dua hal yang tidak dapat dipisahkan dalam pembelajaran piano. Sight singing (menyanyi) notasi melodi pada etude dibaca dengan solmisasi atau movabel "do".

Penerapan sight singing pada salah satu materi etude dari buku Beyer, Op. 101, Nomor 58 dilakukan dengan membaca dan menyanyikan melodi dari etude tersebut, secara bersama-sama terlebih dahulu. Setelah dapat membaca dengan lancar, kemudian mempraktikkan pada instrumen piano sesuai dengan penjariannya, baik secara kelompok ataupun individu. Berikut gambar proses penerapan sight singing pada materi etude.

Bentuk melodi materi etude dari buku Beyer, Op. 101, Nomor 58 yang dibaca dan dinyanyikan oleh para mahasiswa sebelum dimainkan dalam piano adalah sebagai berikut.
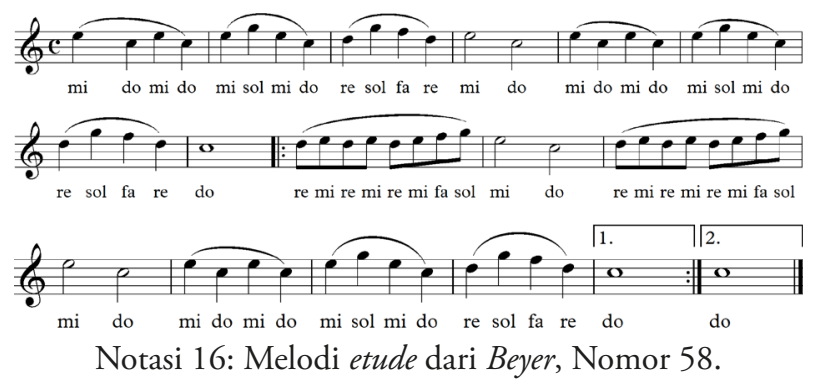

Selanjutnya penerapan sight singing pada etude 50 Kleine Etuden dari J.C Beuk Nomor 43 dan Duvernoy, Op. 176 dari Ecole Primaire Nomor 3. Proses penerapannya sama seperti etude Beyer yaitu dengan membaca dan menyanyikan melodi dengan solmisasi dari etude tersebut secara bersamasama terlebih dahulu. Setelah dapat membaca dengan lancar, kemudian mempraktikkan pada instrumen piano sesuai dengan penjariannya, baik secara kelompok ataupun individu. Berikut bentuk notasi melodi etude 50 Kleine Etuden, dari J.C Beuk Nomor 43.
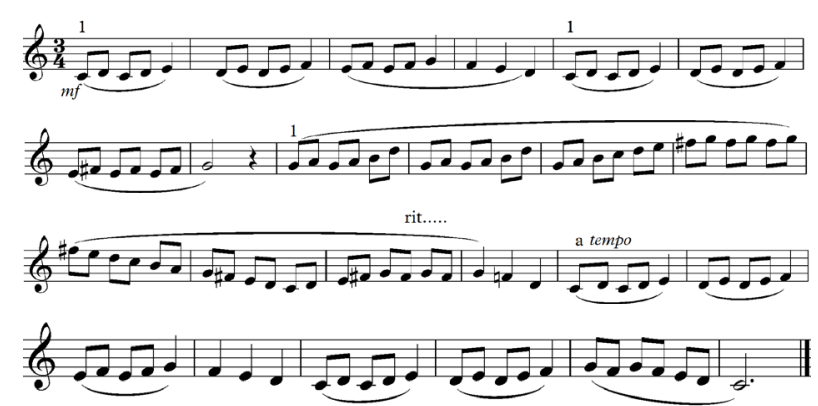

Notasi 17: Melodi etude 50 Kleine Etuden, Nomor 43.

Penerapan sight singing pada sonatine dari Oscar Bolck, Op. 30, bagian 1, 2, 3dan sonatinen dari J.B. Wanhal, Op. 41 bagian 1, 2. Proses penerapannya sama seperti etude yaitu dengan membaca dan menyanyikan melodi dengan solmisasi dari sonatine tersebut, secara bersama-sama terlebih dahulu. Setelah dapat membaca dengan lancar, kemudian mempraktikkan pada instrumen piano sesuai dengan penjariannya, baik secara kelompok ataupun individu. Berikut bentuk notasi melodi sonatine II dari Oscar Bolck, Op. 30, bagian 1.
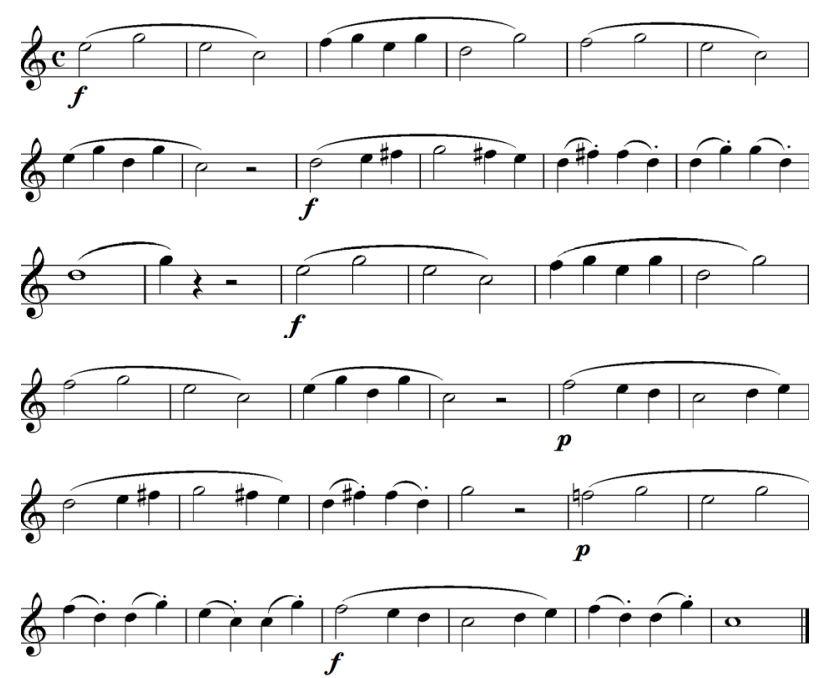

Notasi 18: Melodi sonatine II dari Oscar Bolck, Op. 30, bagian 1.

Penerapan sight singing pada materi buah musik atau lagu yang berjudul "LULLABY" dan "Walts From Coppellia" diambil dari buku "Teacher's Choice for the Young Pianist". Proses penerapannya sama seperti etude dan sonatine yaitu dengan membaca dan menyanyikan melodi dengan solmisasi dari lagu tersebut, secara bersama-sama terlebih dahulu. Setelah dapat membaca dengan lancar, kemudian mempraktikkan pada instrumen piano sesuai dengan penjariannya, baik secara kelompok ataupun individu. Berikut bentuk notasi melodi salah satu lagu yang berjudul "LULLABY". 


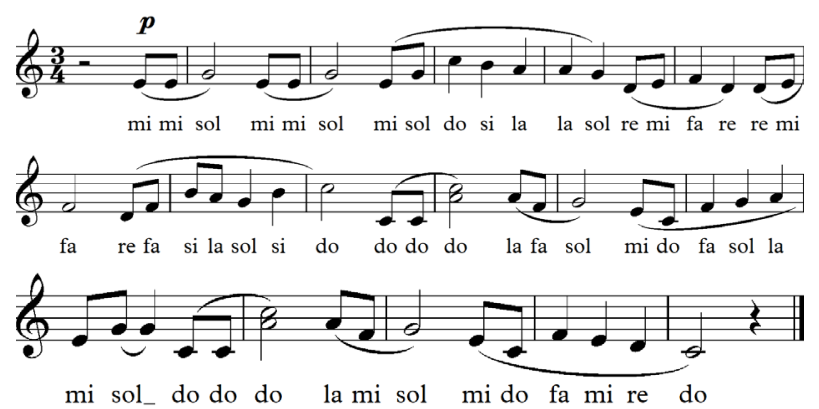

Notasi 19: Melodi sonatine II dari Oscar Bolck, Op. 30, bagian 1.

Setelah dilakukan penerapan sight singing dalam proses pembelajaran Instrumen wajib Piano I, maka dilakukan evaluasi melalui penilaian. Hasil penilaian dari evaluasi proses pembelajaran tersebut, secara umum mengalami peningkatan. Hal ini dapat dilihat dari tingkat keberhasilan mahasiswa melalui nilai yang telah dicapai. Mahasiswa yang mengambil mata kuliah Instrumen Wajib Piano I, secara keseluruhan dapat berhasil dengan baik dan bisa lulus semua. Selain mahasiswa bisa berhasil lulus semua, dengan penerapan sight singing proses pembelajaran juga menjadi lebih menyenangkan.

\section{Kesimpulan}

Berdasarkan pemaparan hasil yang telah dicapai, maka dapat disimpulkan bahwa proses pembelajaran Instrumen Wajib Piano I di Prodi Pendidikan Musik dapat dilakukan melalui beberapa tahap. Proses pembelajaran Instrumen Wajib Piano I diawali dengan perencanaan membuat kontrak kuliah dan RPS (Rencana Pembelajaran Semester). Kemudian melaksanakan proses pembelajaran sesuai rencana program yang disusun. Selanjutnya dilakukan evaluasi hasil pembelajaran melalui penilaian praktik instrumen piano. Proses pembelajaran mata kuliah Instrumen Wajib Piano I diberikan materi secara praktik tentang langkahlangkah dan teknik dasar bermain instrumen piano dengan penjarian yang baik dan benar. Mata kuliah ini diberikan kurang lebih 16 kali pertemuan, meliputi teknik berupa tangga nada, trinada, kadens. Selanjutnya materi beberapa etude dari buku Beyer, Op. 101, Nomor 58 dan 59, buku 50 Kleine Etuden dari J.C Beuk Nomor 43 dan Duvernoy, Op. 176 dari Ecole Primaire Nomor 3.

Penerapan sight singing dalam pembelajaran Instrumen Wajib Piano I, dilakukan untuk materi etude, sonatine dan lagu. Dalam proses pembelajaran Instrumen Piano diawali dengan sight reading (membaca) dan sight singing (menyanyi) notasi melodi etude baik secara berkelompok maupun individu. Sight reading (membaca) dan sight singing (menyanyi), dua hal yang tidak dapat dipisahkan untuk belajar Instrumen Piano. Sight singing (menyanyi) notasi etude dilakukan dengan solmisasi atau movabel "do", setelah dapat membaca dengan lancar, kemudian memainkan piano sesuai penjariannya. Penerapan sight singing pada materi etude dilakukan dengan membaca dengan menyanyikan melodi secara bersamasama terlebih dahulu, kemudian dimainkan pada instrumen piano baik kelompok ataupun individu secara bergantian. Dampak dari penerapan metode Sight singing lebih efektif untuk meningkatkan kemampuan belajar membaca notasi musik. Selain itu, mahasiswa bisa lebih berekspresi, terkesan menyanyi dengan mengiringi sendiri.

\section{Kepustakaan}

Akbari, Achmad Syawal dan Bambang Sugito. 2018. "Tinjauan Harmoni Pada Karya Musik 'Fire Symphony'." Jurnal Mahasiswa UNESA, $8(1), 1-12$.

Aley, Rere. 2001. Cara Mudah Memainkan Beragam Alat Musik. Jakarta: Flash Books.

Banoe, Pono. 2003. Teori Dan Pengetahuan Umum Musik "Pengantar Pengetahuan Harmoni. Yogyakarta: Kanisius.

Djamarah, Syaiful Bahri. 2012. Guru Dan Anak Didik Dalam Interaksi Edukatif. Jakarta: PT. Rineka Cipta.

Firmansyah, Dani. 2015. "Pengaruh Strategi Pembelajaran Dan Minat Belajar Siswa Trehadap Hasil Belajar Matematika.” Jurnal Pendidikan UNSIKA, 3(1), 34-44.

Fitri, Eka Annisa, Sri Saparahayuningsih, dan Nesna Agustriana. 2013. "Perencanaan Pembelajaran Kurikulum 2013 Pendidikan Anak Usia Dini." Jurnal Potensia PG-PAUD FKIP UNIB, 2(1), 1-13.

Gunara, S. 2016. "Pemanfaatan Bahan Sight Reading dalam Pembelajaran Piano." RITME: Jurnal Seni dan Desain serta Pembelajarannya, 
2(1), 78-85.

Husna, Mugi Nurul, Yudi Kusmayadi, dan Diyah Latihah. 2016. "Penerapan Metode Solfeggio Untuk Siswa Sekolah Tingkat Menengah Pertama (SMP) Kelas VII." Jurnal Penelitian Pendidikan, 17(1), 55-59.

Indrawan, A., dan Kustap. 2015. "Adaptasi Konserto Pada Ensambel Gitar Sebagai Upaya Pengayaan Bahan Ajar Mata Kuliah Ensambel." Resital: Jurnal Seni Pertunjukan, 16(2), 95-103.

Kodijat, L. 2008. Penuntun Mengajar Piano. Jakarta: Djambatan.

Last, J. 2012. Interpretation In Piano Study. New York: Oxford University Press.

Latifah, D. 2012. "Evaluasi Mata Kuliah Piano Untuk Mneghasilkan Guru Musik Di Sekolah.” Jurnal Penelitian Dan Evaluasi Pendidikan, 16(2), 457-73.

Latifah, D. 2013. "Relevansi Proses Pembelajaran Mata Kuliah Instrumen Pilihan Wajib Piano Dengan Tujuan Kurikulum FPBS UPI.” Jurnal Harmonia: Pengetahuan Dan Pemikiran Seni, 13(1), 19-28.

Mulyono, E. S. 2008. Panduan Dasar Bermain Jazz. Jakarta: Kawan Pustaka.

Nadzir, M. 2013. "Perencanaan Pembelajaran Berbasis Karakter." Jurnal Pendidikan Agama Islam, 2(2), 339-52.

Naenggolan, O. T. P. 2019. “Strategi Menghafal Penjarian Tangga Nada Dalam Mata Kuliah Instrumen Dasar I." Resital: Jurnal Seni Pertunjukan, 20(1), 52-59.

O'Brien, R. 2001. An Overview of the Methodological Approach of Action Research. Toronto: Faculty of Information Studies.

Purnawan, Ary dan Gunawan. 2000. "Upaya Peningkatan Efektifitas Pembelajaran Bahasa Inggris Di SLTP I Pengasil Kulon Progo.” Jurnal Penelitian dan Evaluasi, 2(3), 69-96.
Rahdiyanto, D. 2012. "Penelitian Tindakan Kelas (Pengertian, Prinsip dan Karakteristik PTK).” Yogyakarta: Fakultas Teknik Universitas Negeri Yogyakarta.

Rusdewanti, P.P. 2015. “Upaya Peningkatan Hasil Belajar Piano 2 Melalui Metode Sight Reading Di Jurusan Pendidikan Seni Musik FBS UNY." IMAJI: Jurnal Seni dan Pendidikan Seni, 13(2), 78-92.

Sanjaya, W. 2011. Penelitian Tindakan Kelas. Jakarta: Kencana Prenadamedia Group.

Slameto. 2003. Belajar Dan Faktor-Faktor Yang Mempengaruhinya. Jakarata: Rineka Cipta.

Sulasmono, Putut. 2013. "Peningkatan Kemampuan Vokal Melalui Metode Solfegio.” Jurnal Harmonia: Pengetahuan Dan Pemikiran Seni, 13(1), 45-5.

Sumaryanto, F. T. 2005. "Efektifitas Penggunaan Metode Solfegio Untuk Pembelajaran Bermain Musik Di Sekolah Dasar." Jurnal Harmonia: Pengetahuan dan Pemikiran Seni, 6(2).

Sumiati. 2009. Metode Pembelajaran. Bandung: CV Wacana Prima.

Susilowati, Sajidan dan Murni Ramli. 2018. "Keefektifan Perangkat Pembelajaran Berbasis Inquiry Lesson untuk Meningkatkan Ketrampilan Berpikir Kritis Siswa.” Jurnal Penelitian Dan Evaluasi Pendidikan, 22(1), 49-60.

Sutikno, S. 2009. Belajar Dan Pembelajaran. Bandung: Prospect.

Utomo, Wadiyo dan Udi. 2018. "Pengembangan Materi Ajar Seni Budaya Sub Materi Musik Pada Sekolah Umum Jenjang Pendidikan Dasar." Resital: Jurnal Seni Pertunjukan, 17 (2), 87-97.

Winata, D. A. 2015. Pembelajaran Piano Klasik Untuk Siswa Tingkat Dasar Di Maestro Music School Semarang. Semarang: Universitas Negeri Semarang. 